\title{
Students' interest in Arabic language learning: the roles of teacher
}

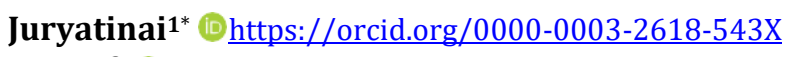 \\ Amrin $^{2}$ (1) https://orcid.org/0000-0002-0113-1024 \\ ${ }_{1}^{1}$ Pendidikan Sekolah Rendah, Universiti Pendidikan Sultan Idris Malaysia, Malaysia \\ ${ }^{2}$ Arabic Language Education, UIN Syarif Hidayatullah Jakarta, Indonesia
}

\begin{abstract}
Arabic language education is a compulsory subject in Madrasah (Primary education level) under the auspices of the Ministry of Religious affairs. The students' interest in Arabic language learning in Madrasah Aliyah Nurul Haq Rite Indonesia was very low. This is due to the students' dislike of Arabic that demands the students to think, memorize, and be proficient in speaking as well as other skills. The current learning activities are non-varied and teacher-centered learning models. This study aims to determine the role of teachers in increasing students' interest in Arabic learning. This study used a qualitative approach with field studies. Data collection techniques were interview, observation, and documentation. The data analysis techniques were in the form of data reduction, data display, and conclusion drawing. The results of this study on the roles of teachers indicate that; (1) the teacher provides motivation and guidance for every Monday ceremony and Imtaq activities on Friday, (2) the teacher only uses textbooks without semester learning plans and other learning tools, (3) the teacher uses non-varied methods ( such as the lecture and discussion method), (4) the teacher provides an assessment of learning outcomes, (5) the teacher provides evaluation or tests, (6) the teacher gives praise to students, and (7) the teacher punishes students who do not do assignments. The results of this study contribute as practical insights for teachers, especially Arabic teachers in maximizing their roles to increase interest in learning Arabic in schools.
\end{abstract}

\section{ARTICLE INFO}

Keywords:

Arabic education ; roles of the teacher; students' interest

\section{Article History:}

Received: 02 March 2021

Revised: 05 April 2021

Accepted: 20 April 2021

Published: 10 May 2021

\section{How to Cite in APA Style:}

Juryatinai \& Amrin. (2021).

Students' interest in Arabic language learning: the roles of teacher. Journal of Educational Management and Instruction, 1(1), 4049.

\section{Introduction}

Education is the first basic foundation in the development of human resources. Education is intended to establish people who fear God, have a noble character, are independent and creative, as well as become a golden generation for the nation for taking part in the community development (UU No. 20 Year 2003). In order to achieve educational goals, education policies are necessary as an integrated, proportional, and comprehensive step in organizing, managing, and designing education.

Education as institutions that contribute to developing and constructing the nation and society consists of three elements, namely informal, formal, and non-formal institutions. Madrasa as an official institution (formal) provides curriculum policies referring to the 1945 Constitution with an integrated and proportional curriculum (Pransiska \& Aulia, 2018). The curriculum is made to realize the ideals of education nationally. Thus, the patterns, methods, and the role of educators in learning are the keys to creating quality output. Education can run well and dynamic if the teacher has the responsibility and function in fostering, educating, and transforming knowledge as well as being a good role model. 
Learning will run well if the roles of those with functions and responsibilities bring benefit to the education and community. As the main focus, Arabic as a foreign language is one of the Madrasah subjects oriented towards mastery and proficiency in speaking, writing, listening, and so on. Arabic is also a communication tool at the international level. It is a necessity for institutions/madrasah to improve and develop the Arabic language curriculum. Education patterns should be arranged in such a way to customize the culture and demographics according to the local community (Yusoff, 2012). Arabic is the language of kalamullah that was sent down by Allah to the Prophet Muhammad through the archangel Gabriel for Mankind on Earth. Therefore Arabic has a legal correlation with Islamic law so that it is obligatory for every Muslim to learn Arabic. It is oriented towards the necessity of prioritizing skills in understanding the rules of nahwa and shorof and other skills (Zulhannan, 2014).

In the context of development, Arabic is a primary need for students to be mastered as a basic intellectual and spiritual skills in the industrial era 4.0 and complex civil society. In the implementation at madrasas, students' interest becomes a problem in learning. Many students think Arabic is more difficult than English. This paradigm makes students less interested and even less excited about Arabic learning. The teacher must take a role in dealing with and resolving the obstacles. The problem must be resolved in an interactive, proactive, inspirational, and fun way to motivate students to participate actively and providing sufficient space for the initiative, creativity, intellectuality, and independence according to the talents, interests, physical, and psychological development of students (UU No. 14 Year 2005 on Teachers and Lecturers)

Madrasah Aliyah Nurul Haq Rite, Bima Regency, Indonesia has missions and programs to improve the quality of Arabic language education. In its implementation, the Arabic learning encountered obstacles and problems, especially the problem of student interest in Arabic learning. Students find difficulties in learning resulting in each mid- or end-of-semester assessment fielded unsatisfactory (low) scores. The students who got satisfactory scores were $25 \%$ while those who were unsatisfactory were $85 \%$ of 195 students. This indicates that the role of the principals and teachers in overcoming and finding solutions to solve problems is very important. Efforts to increase the interest and quality of Arabic learning require synergy and roles from various parties. Effective learning will be carried out if the learning is prepared properly and correctly. Students can speak proficiently and confidently, which are some of the goals of learning. Everything must be carefully encouraged by educators who are responsibility for the tasks that must be carried out properly (Imam et al., 2021). The success of the teacher in learning relies heavily on oriented and targeted methods and techniques used. Conversely, failure occurs when the method igniting good interest in the learning process making students become independent, fun, and creative (Hisyam et al., 2002).

Based on empirical observations and interviews as preliminary information from the school, it showed indicators of the problem of interest in Arabic learning. First, the students come from different schools such as public schools, madrasas, or Islamic boarding schools. The variety of backgrounds will affect the level of understanding. Second, the teacher's lack of motivation in creating creative learning. Third, students fear as they think Arabic is a difficult language so that students' mental readiness is stagnant and not optimal. Fourth, lack of adequate facilities eliminates the independence of students in Arabic learning. Fifth, the use of methods and techniques that are not varied and do not support the potential and abilities of students with their potentials.

Based on the problems and facts that occurred Madrasah Aliyah Nurul Haq Rite, Bima Regency, Indonesia, it is an important discourse, so it is necessary to study the pattern of education policies that focus on the role of teachers to examine the probabilities that occur in the scope Madrasah Aliyah Nurul Haq Rite, Bima Regency, Indonesia holistically and deeply. The focal point of the problem studied is how the 
teacher's role in increasing interest in learning Arabic. Research is expected to contribute both theoretically and practically. The theoretical contribution of this research is to develop or formulate policies and innovations on the role of teachers as well as the theory of Arabic language learning in particular or learning in general. As a practical matter; first, as an effort to provide an overview of the problems of learning Arabic in Madrasah Nurul Haq Rite, Bima Regency, Indonesia to be used as material for consideration and reference by the government and related parties in formulating policies according to student needs and school conditions. Second, this research is expected to be an instrument and material for evaluating Arabic learning in Madrasah Aliyah Nurul Haq Rite, Bima Regency, Indonesia. Third, as a basis and reference for other schools in maximizing the role of teachers, especially in increasing interest in learning Arabic in Bima Regency.

\section{Method}

\section{Research context and participants}

The research approach used is a qualitative approach that aims to obtain information by conducting case studies to explore the role of teachers, interest in learning, and students' resilience in learning Arabic at Madrasah Aliyah Nurul Haq Rite, Bima Regency, Indonesia. This research uses interview, observation, and documentation techniques (Sugiyono, 2018; Lexy J. Moloeng, 2009). The researcher involved 15 students as informants who were randomly selected from each class, namely grades 10 , 11 , and 12 , as well as the principal, vice principal in curriculum, deputy principal in student affairs, and students as students.

\section{Instrument and data collection}

Data collection was carried out by direct observation by going to the field to see the condition of the Madrasah, such as the condition of the students, the condition of the teacher, the role of the teacher, the methods used by the Arabic teacher, and the resilience of the educational environment at Madrasah Aliyah Nurul Haq Rite, Bima Regency, Indonesia. The second method is by conducting in-depth and structured interviews to obtain information and in-depth understanding of school programs, policies in schools, challenges, opportunities, circumstances, needs, student resilience in the educational environment of Madrasah Aliyah Nurul Haq Rite, Bima Regency, Indonesia to obtain valid data, reliability, comprehensive and complete to be processed and analyzed to answer and find solutions to the role of teachers and learning interests oriented to Arabic learning. Third, documentation to obtain data on students, teachers, school facilities, and infrastructure.

\section{Data analysis}

The data obtained based on the results of observations, interviews, and documentation were analyzed using reduction, data presentation, and drawing conclusions based on the theme of the research problem (Shobron \& Rosyadi, 2020). In the data analysis process, the researcher summarizes the detailed data records obtained based on the themes and problems being studied. After that, the researcher selects, classifies, and focuses the data obtained based on the themes and problems being studied. Then the researcher presents the data by sequencing (arranging) logically and systematically as the basis for the researcher to conclude.

\section{Results}

Based on the results of observations, interviews, and documentation, it was revealed that Madrasah Aliyah Nurul Haq Rite, Bima Regency, Indonesia is a private Madrasah Aliyah managed by the Nurul Haq Foundation which is chaired by Mr. Kihajar, S. Pd.I., M. Si as well as the founder and owner of the foundation which was founded in 
2011. The madrasah is located in Desa Rite with a vision mission of a madrasa which develops language as a language center and a religious center in the Bima area and particularly in Ambalawi District.

This madrasah is under the auspices of the Ministry of Religion, Bima Regency, West Nusa Tenggara Province Indonesia, and its location is very strategic, where vehicles or transportation are very smooth so that it is very easy to reach by the community. Madrasah Aliyah Nurul Haq Rite, Bima Regency, Indonesia is the only private Madrasah Aliyah in the Rite Village area with several other supporting schools such as Madrasah Tsanawiyah Nurul Haq Rite,, Muhammadiyah Rite Junior High School, Ambalawi 1 Public Junior High School, Bima Regency, Indonesia.

As an institution that is still young, of course in the process of teaching and learning activities oriented towards National education goals concerning the SISDIKNAS Law No. 20 of 20023 and Permenag No. 2 of 2008 concerning standards and competency of graduates and content in Islamic education and Arabic language education Apart from Islamic and Arabic education, it is also scientific education (general) and extracurricular activities. The curriculum used is the K13 curriculum.

This is based on the results of an interview with Mrs. Julfida PS, SP. Pd.I as the Principal said that " Madrasah Aliyah Nurul Haq Rite, Bima Regency, Indonesia uses the $\mathrm{K}-13$ curriculum following the applicable regulations and the learning process still uses textbooks of teaching materials from the ministry with integration with various madrasa culture which consists of three abilities, namely intelligence (cognitive), morals (affective) and skills (psychomotor). Learning using the lecture method, a discussion that is centered on the teacher (center teacher) Furthermore, he said that $90 \%$ of all students who study at Madrasah Aliyah Nurul Haq Rite, Bima Regency, Indonesia are classified as poor (poor) and on average from schools from public schools and also from Madrasah Tsanawiyah Nurul Haq Rite, Bima Regency, Indonesia."

Regarding the learning model and methods used in Madrasah Aliyah Nurul Haq Rite, Bima Regency, Indonesia, it is more on the method of lecturing, discussion, question, and answer which is teacher-centered (center teacher and pegged only to textbooks. Students as the most important in the education component are the objects and subjects of educational activities. Madrasah Aliyah Nurul Haq Rite, Bima Regency, Indonesia in the 2020-2021 lessons amounted to 195 students with categories of male 87 and female 108 consisting of grade 10,11 , and grade 12 .

The teacher as an integral part of educational assignments based on observations and interviews amounted to 23 people with their potential. Only $65.3 \%$ of professional competence can. The teachers with pedagogic competence were $75.8 \%$. So that it has an impact on the quality and quality of knowledge transformation on students with $25 \%$ results which are good (satisfactory), $85 \%$ are not satisfactory.

\section{Discussion}

\section{Arabic Learning in Madrasah Aliyah Nurul Haq Rite}

Madrasah Aliyah Nurul Haq Rite, Bima Regency, Indonesia uses the K-13 curriculum. Learning activities used textbooks from the ministry with the integration of various madrasah cultures consisting of intelligence (cognitive), morals (affective), and skills (psychomotor). Learning by using the lecture method, which is teacher-centered. The approach taken no longer puts forward creativity and innovation. The approach was very passive in that there was no role for teachers as educators in formulating steps and roles in designing learning frameworks and methods igniting students' interest and enthusiasm for learning (Nugroho \& Mutiaraningrum, 2020: Wisman, 2017).

Teachers must have competencies in educating and fostering students, First, pedagogic that oriented on class control and management. Currently, the teacher is only based on textbooks. This means that the teacher is very monotonous without considering the cultural conditions and abilities of students. The teacher only teaches 
without evaluating the resulting output. They just abort their obligations as teachers without further acts. Second, professional in that teachers provide material that cannot be mastered by students as it uses the Arabic language, which is considered too difficult. Thus, the response of students is very slow (Sabic-El-Rayess, 2020).

The students in Madrasah Aliyah Nurul Haq Rite, Bima Regency, Indonesia have varied educational backgrounds such as from public schools, from a poor and underprivileged families with a lack of knowledge. It greatly impacts interest and learning outcomes. The interest and enthusiasm of the students in Madrasah Aliyah Nurul Haq Rite in learning Arabic languages are minimal. Hence, it impacted educational outcomes that are not optimal.

\section{The role of teachers in increasing Arabic learning interest}

The role of teachers in increasing Arabic learning interest is divided into teachers' role as educators, educators, professional, mentor, teacher, coach, advisor, leader, role model, and community members.

\section{Teachers' Role as Educators}

According to Wiji Suwarno in his book Kunandar,, educators are people who deliberately influence others to get a higher human level (Kunandar, 2011). As an educator, teachers must be able to educate with compassion towards students. This is because the teacher is part of the qualified education as an educator. They are given moral responsibility to self, family, and society. The teacher should be enthusiastic in educating participants without being arrogant and apathetic with a good emotional approach. The teacher applied the teaching and learning process by carrying out the process of transforming knowledge as a moral responsibility. It also has an impact on the inheritance of the values of interest in Arabic learning. A good emotional approach makes it easy for students to become familiar. Students should have the willingness for independent learning, others, and the environment so that it has an impact on increasing interest and quality of Arabic learning (Saada, 2020).

\section{Teachers' Role as a Professional}

The teacher as a professional refers to the acts carried out by a person as a source of living that requires expertise, proficiency, or skills that meet quality standards, certain norms, and professional education (Law Number 14 of 2005 concerning Teachers and Lecturers). Teachers are a profession that has special expertise in educating and teaching who hold roles and responsibilities in the education. The role of teachers is needed to increase students' interest in learning with intellectual intelligence (knowledge), emotional (morals), and psychoanalytic (skills). The role of the teacher greatly affects the success of the quality and morality of students in increasing interest in learning. The efforts and role of teachers in improving the quality of teachers as professionals in teaching and educating, especially Arabic learning by following training and workshops held by the Ministry of Religious affairs, schools, or other institutions. The activity was formed as a means of developing knowledge and teaching materials, as well as experience as one of the steps to improve the quality of education. Hence, it will ultimately influence interest in learning and the quality of Arabic learning (Zembylas \& Loukaidis, 2020).

\section{Teachers' Role as a Mentor}

Teachers act as an educator and professional by sharing knowledge based on lesson written in the form of a lesson plan of Arabic language learning. As a supervisor, they must start identifying competencies and physical conditions by providing students with a sense of security as a comprehensive anticipatory and integrated step in formulating and developing students' talents and interests so that they are focused. The 
teacher must show a sense of concern for students. Guiding is a necessity in developing students' intellectual and abilities as well as directing towards success by emphasizing self-confidence and a spirit of quality learning (E. Mulyasa, 2007). At Madrasah Aliyah Nurul Haq Rite, Bima Regency, Indonesia, the teacher acts as a guide for students in increasing their interest in Arabic by teaching which focuses on the conditions and potential of students in following Arabic language learning. The diversity of character and attitudes of students requires teachers to being able to guide and facilitate students. When students do disrespectful actions, the teacher must do it with full attention without losing his dignity as a teacher (Kidd et al., 2020).

\section{Teachers' Role as Teachers}

The teacher has the duty and responsibility to educate students. The teacher teaches for development, competencies, and understanding (Mulyasa, 2007). In the teaching process in increasing the interest and quality of Arabic learning at Madrasah Aliyah Nurul Haq Rite, Bima Regency, Indonesia, a teacher prepares models and techniques in learning with a socio-psycho approach for students with various character, culture, and social background. Besides, the teacher provides materials that attractive and motivative that lead to an interest in learning and success. The teacher also encourages students not only to focus on learning only at school but wherever and whenever and to practice the knowledge gained (Wisman, 2017).

\section{Teachers' Role as Coach}

As coaches, teachers need to practice intellectual and motor. In increasing interest in Arabic learning which is based on the quality of learning, teachers must have skills in preparing activities and learning and at making students excited in learning with technology as well as skilled in using props. Teachers should be skilled in evaluating and assessing learners. In increasing student interest, the teacher trains students in memorizing mudrodah, practicing speech, and carrying out extracurricular activities in the form of Arabic learning groups and so on (Karastoyaiiov et al., 2019).

\section{Teachers' Role as Advisor}

Teachers as advisors act as parents in providing comfort to confide the students. A person to talk to when the students face learning difficulties, financial difficulties, family and social problems, and identity crisis. Students' problems and difficulties will have an impact on learning success. The teacher has a role in advising and giving spirit to students in overcoming the problems faced, especially problems and interests related to learning Arabic (Heyden et al., 2020).

\section{Teachers' Role as Leaders}

As a leader, the teacher is at the forefront of increasing interest in learning Arabic by innovating and creativity in learning and teaching that can help and facilitate students in learning so that they have cognitive, affective, and psychomotor competencies (Aziz, 2017). In its implementation at Madrasah Aliyah Nurul Haq Rite, teachers must provide confidence, enthusiasm, and motivation to students. Teachers must be leaders who are easily accessible to emulate. Thus students will be confident with the knowledge and both at school and outside of school.

\section{Teachers' Role as Role Models}

Teachers should be role model in increasing the interest and quality of Arabic learning. Madrasah Aliyah Nurul Haq Rite requires teachers to be and role models both outside of school and within the school environment, especially in the teaching and learning process. The teacher should provide a polite language style, a good appearance, 
attitude, and practice Arabic with students in a fun way making students to be motivated in Arabic learning (Biwer et al., 2020).

\section{Teachers' Role as Community Members}

In increasing interest in learning, teachers as members of the community can link school life with community life by introducing the culture, traditions, and society of the surrounding community. Teachers must interpret culture and social content into Arabic learning. Integration and collaboration with local values and culture will have an impact on the preservation of local community values. The teacher at Madrasah Aliyah Nurul Haq Rite are local people. Most of the students come from the surrounding area, namely Rite, Kole and Tolowata Villages. As members of the community, they must be able to present real-life Arabic as a future opportunity that is very much needed when becoming alumni and engaging in community life. By looking at the stimulus and opportunities, of course, it will present the students' interest and quality in Arabic learning (Juraschek et al., 2020).

\section{Supporting and Inhibiting Factors in Increasing Interest and Quality or Arabic Language Learning \\ Supporting Factors}

In carrying out teaching and learning activities, a teacher must understand the supporting factors for improvement. It is not always a smooth process without any obstacles. First, the vision and mission of the madrasa to develop a language center and a center for a religion in the Bima area and especially in the Ambalawi district. As an educational institution oriented towards Islam which is rahmatan lil'alaamiin as a monotheistic religion that has holy books and hadith in Arabic. The mission is to make the language a means of communication and the development of knowledge. The Madrasah Aliyah Nurul Haq Rite, Bima Regency, Indonesia is expected to produce the best alumni who participate in building and caring for traditions by creating good and correct language quality (Pransiska \& Aulia, 2018).

The mission and vision become supporting factors in increasing the quality of learning by strengthening language proficiency. Second, cooperation with related parties (stakeholders) (Herawati \& Ramadhan, 2020). The role of the community and related parties of personals, groups, institutions, professional organizations, and entrepreneurs is essential in the quality control of educational services. A collaboration is built as a source, implementation, and use of learning outcomes. The essence of cooperation as a form of care, sympathy, and support includes education, infrastructure, social. and more specifically financially (Baidi et al., 2020). Schools are part of society that have a positive impact on Madrasah Aliyah Nurul Haq Rite as input in the form of activities in instilling trust from the public, especially in the development of Arabic which is the goal of madrasas in creating quality output (alumni). Third, the development of all elements within the scope of Madrasah Aliyah Nurul Haq Rite. Competence development in the form of Arabic teacher training to provide reinforcement of teachers' ideas and creativity in increasing the interest and quality of students (Herawati \& Ramadhan, 2020).

\section{Inhibiting Factors}

In increasing the interest of Arabic learning, teachers encountered several problems including inadequate facilities and infrastructure. Arabic teachers also experience difficulties in carrying out the teaching and learning process (Mulyadi et al., 2020). As an Arabic teacher, Niswah said that the difficulty was the lack of language laboratory facilities. Language and internet access are difficult to get, too. Students rely on textbooks provided. Students experience learning pessimism lacking interest. Further, the diverse characters of students create difficulties for teachers in formulating 
the methods and lessons. Teachers must think extra in formulating lesson plans to increase interest and quality of learning Arabic. Students who come from public schools do not learn Arabic at all, this has implications for the interest in learning Arabic (Mustaqim, 2017).

Third, students' lack of awareness in learning Arabic. The problem of learning awareness is very crucial in increasing interest. Students were indifferent in the learning process. If students perceive Arabic as something easy, it will accelerate their ability to master Arabic. Fourth, the lack of parental attention to their child's education. Interest and quality in Arabic learning are weakened when parents do not pay attention to their children. This is difficult to solve since this is the responsibility of parents. Actually, parents must motivate and encourage their children. Children should be trained carefully so that they learn to be creative and independent in life (Armstrong et al., 2020).

Fifth, madrasah's financial limitations. Finance is one of the supporting factors for the development of educational facilities and competencies. Financial support is required. The lack of financial support affects the interest and quality of Arabic learning. Sixth, the financial shortcomings of the students' parents. It is difficult for parents to provide facilities and other support to meet their children's educational needs. It has implications for increasing interest and quality in Arabic learning. The last problem deals with the teacher's competence. Teachers theoretically must have four competencies in teaching and learning, namely personal, professional, pedagogical, and social competence (Abdurrahman et al., 2015). The results show the lack of pedagogic and professional competencies of the teacher in teaching the Arabic language. It impacted the class delivery, especially on the interest and quality of language learning.

\section{Conclusion}

The research objective was to determine the role of the teacher in increasing interest in learning Arabic by using the method of interviewing, observation and documentation. The results of this study indicate that; (1) the teacher provides motivation and guidance for every Monday ceremony and Imtaq activities on Friday, (2) the teacher only uses textbooks without semester learning plans and other learning tools, (3) the teacher uses non-varied methods ( such as the lecture and discussion method), (4) the teacher provides an assessment of learning outcomes, (5) the teacher provides evaluation or tests, (6) the teacher gives praise to students, and (7) the teacher punishes students who do not do assignments. The results of this study contribute as practical insights for teachers, especially Arabic teachers in maximizing their role to increase interest in learning Arabic in schools. The limitation of this study is that the researcher only uses a small number of samples and applies it to only one subject, it is hoped that the next researcher will be able to research with the use of more samples and be able to research other subjects.

\section{References}

Abdurrahman, M., Suherman, A., Masor, M., \& Fadhlillah, A. M. I. (2015). Tantangan Guru Bahasa Arab Madrasah Aliyah Dalam Perspektif Kompetensi Pedagogik Dan Profesional. ARABIYAT : Jurnal Pendidikan Bahasa Arab Dan Kebahasaaraban, 2(1), 43-58. https://doi.org/10.15408/a.v2i1.1513

Armstrong, L., Harding, F., Critchley, J., McNarry, A. F., Myatra, S. N., Cooper, R., \& Baker, P. A. (2020). An international survey of airway management education in 61 countries†. British Journal of Anaesthesia, 125(1), e54-e60. https://doi.org/10.1016/j.bja.2020.04.051

Aziz, A. (2017). Communication of Educators And Learners In Islamic Education. Mediakita, 1(2), 173-184. https://doi.org/10.30762/mediakita.v1i2.365

Baidi, Heldy, R. P. P., \& Junaidah. (2020). The effect of leadership style and work motivation on work productivity for teachers in all state junior high schools of 
surakarta. Universal Journal of Educational Research, 8(3D), 67-72. https://doi.org/10.13189/ujer.2020.081710

Biwer, F., Egbrink, M. G. A. oud., Aalten, P., \& de Bruin, A. B. H. (2020). Fostering Effective Learning Strategies in Higher Education - A Mixed-Methods Study. Journal of Applied Research in Memory and Cognition, 9(2), 186-203. https://doi.org/10.1016/j.jarmac.2020.03.004

Herawati, Y. \& Ramadhan, H. (2020). The Effect of Implementing Strategy Management on Improving The Quality of Education of Madrasah Aliyah Negeri 1 North Bengkulu. Technium: Social Science Journal, 6(6), 69-87. https://techniumscience.com/index.php/socialsciences/article/view/332/124

Heyden, E., Küchenhof, J., Greve, E., \& Krause, D. (2020). Development of a Design Education Platform for an Interdisciplinary Teaching Concept. Procedia CIRP, 91, 553-558. https://doi.org/10.1016/j.procir.2020.02.213

Hisyam, Z., Bermawy M., Sekar, A. A.,, Rifki, R., (2002). Desain Pembelajaran di Perguruan Tinggi. Yogyakarta. CTSD IAIN Sunan Kalijaga.

Imam M, Putra, H. R., Muharom, F., Hafidah, \& Maslamah. (2021). Self-Efficacy , Job Satisfaction, and Organizational Citizenship Behavior (OCB) For Teachers In All State Primary Schools Of Sukoharjo : A Quantitative Analysis. Elementary Education Online, 20(1), 1149-1154. https://doi.org/10.17051/ilkonline.2021.01.111

Juraschek, M., Büth, L., Martin, N., Pulst, S., Thiede, S., \& Herrmann, C. (2020). Event-based education and innovation in Learning Factories - Concept and evaluation from Hackathon to GameJam. Procedia Manufacturing, 45(2019), 43-48. https://doi.org/10.1016/j.promfg.2020.04.057

Karastoyaiiov, D., Stoiinenov, N., \& Gyoshev, S. (2019). Methods and means for education of people with visual impairments. IFAC-PapersOnLine, 52(25), 539-542. https://doi.org/10.1016/j.ifacol.2019.12.601

Kidd, D., Miner, J., Schein, M., Blauw, M., \& Allen, D. (2020). Ethics across the curriculum: Detecting and describing emergent trends in ethics edufile. Studies in Educational Evaluation, 67(July), 100914. https://doi.org/10.1016/j.stueduc.2020.100914

Kunandar. (2011). Guru Profesional. Jakarta. PT. Raja Grafindo.

Lexy J. Moloeng. (2009). metodologi Penelitian Kualitatif. Bandung. PT. Remaja Rosdakarya.

Nugroho, A. \& Mutiaraningrum, I. (2021). EFL teachers' beliefs and practices about digital learning of English. Edulite: Journal of English Education, Literature and Culture, 5 (2), 304-321

Mulyadi, A., Supriyanto, E., Muthoifin, M., \& Shobron, S. (2020). Upaya Peningkatan Mutu Sekolah Dengan Strateg Bauran Pemasaran Untuk Kepuasan Pelanggan Pada Smp Muhammadiyah Sinar Fajar Cawas Dan Smpit Muhammadiyah an Najah Jatinom Klaten. Profetika: Jurnal Studi Islam, 21(1), 121-128. https://doi.org/10.23917/profetika.v21i1.11654

Mulyasa, E. (2007). Menjadi Guru Profesional: Menciptakan Pembelajaran Kreatif dan Menyenangkan. Bandung. PT.Remaja Rosdakarya.

Mustaqim. (2017). Pengaruh Intensitas Penggunaan Bahasa Arab Dalam Pembelajaran Terhadap Keberhasilan Mengajar Guru Pendidikan Agama Islam Di Kota Salatiga Tahun Pelajaran 2015-2016. Tesis. IAIN Salatiga.

Pransiska, T., \& Aulia, A. (2018). Pendekatan Sistem Pembelajaran Bahasa Arab Di Madrasah Mu'Allimin Muhammadiyah Yogyakarta. EDUKASI: Jurnal Penelitian Pendidikan Agama Dan Keagamaan, 16(2), 153-165. https://doi.org/10.32729/edukasi.v16i2.473

Saada, N. (2020). Perceptions of democracy among Islamic education teachers in Israeli Arab high schools. Journal of Social Studies Research, 44(3), 271-280. https://doi.org/10.1016/j.jssr.2020.05.003

Sabic-El-Rayess, A. (2020). Epistemological shifts in knowledge and education in Islam: 
A new perspective on the emergence of radicalization amongst Muslims. International Journal of Educational Development, 73(December 2019), 102148. https://doi.org/10.1016/j.ijedudev.2019.102148

Shobron, A., \& Rosyadi, I. M. (2020). Islamic Education Values in the Tradition of Peta Kapanca of Mbojo Community Tribe in West Nusa Tenggara. Department of Islamic Law Universitas Muhammadiyah Surakarta Indonesia Mut122@ums.ac.id. 29(5), 6802-6812.

Sugiyono. (2018). Metode Penelitian Kuantitatif, Kualitatif dan R\&D. Bandung. CV. Alfabeta.

UU Nomor 14 Tahun 2005 tentang Guru dan Dosen. https://jdih.kemenkeu.go.id/fulltext/2005/14tahun2005uu.htm

UU Nomor 20 Tahun 2003. (2003). Undang-Undang Republik Indonesia No 20 Tentang Sistem Pendidikan Nasional. Jakarta: Direktorat Pendidikan Menengah Umum, 6. http://stpi-binainsanmulia.ac.id/wp-content/uploads/2013/04/Lamp_2_UU202003-Sisdiknas.doc

Wisman, Y. (2017). Effective Communication In Education. Jurnal Nomosleca, 3(2), 646654. https://doi.org/10.26905/nomosleca.v3i2.2039

Yusoff, W. M. W. (2012). The Impact of Prophet Muhammad Motivation Techniques on Students' Performance. Procedia - Social and Behavioral Sciences, 69(Iceepsy), 1700-1708. https://doi.org/10.1016/j.sbspro.2012.12.117

Zembylas, M., \& Loukaidis, L. (2020). Affective practices, difficult histories and peace education: An analysis of teachers' affective dilemmas in ethnically divided Cyprus.

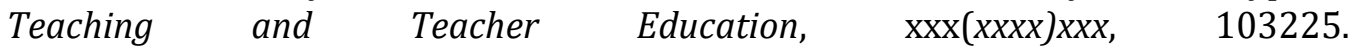
https://doi.org/10.1016/j.tate.2020.103225

Zulhannan. (2014). teknik pembelajaran bahasa arab interaktif. Jakarta: Rajawali Pres. 